\title{
Analisis Industri Kreatif Dalam Memanfaatkan Identitas Kota Melalui Media Baru
}

\author{
Farid Rusdi, Gregorius Genep Sukendro \\ Fakultas Ilmu Komunikasi Universitas Tarumanagara \\ faridr@fikom.untar.ac.id, geneps@ fikom.untar.ac.id
}

\begin{abstract}
Creative industry in Indonesia is growing rapidly cannot be separated from new media support. Utilization of new media by the creative industry attracts potential customers not only from domestic but also from abroad. They can get information about the creative industry through new media. The place where the creative industry is there is also a consideration for potential consumers in determining the choice. In this study aims to find out how the creative industry strategy communicates the attractiveness of the place where they are so that the interest of potential customers. This research will use marketing communication theory and new media. And in analyzing data obtained by researcher will use SOSTAC analysis. In addition to observation and literature study, researchers also conducted interviews with industry parties from two cities that are identical with the creative industries of Bandung and Yogyakarta, which has gained a reputation in overseas markets. From this research found that creative industry players have the potential to attract tourists, especially from abroad.
\end{abstract}

Keyword: creative industries, marketing communications, new media

\begin{abstract}
Abstrak
Industri kreatif di Indonesia berkembang pesat tidak bisa lepas dari dukungan media baru. Pemanfaatan media baru oleh industri kreatif menarik minat calon konsumen tidak hanya dari dalam negeri tapi juga dari luar negeri. Mereka bisa mendapatkan informasi tentang industri kreatif melalui media baru. Tempat di mana industri kreatif itu ada juga menjadi pertimbangan bagi calon konsumen dalam menentukan pilihannya. Penelitian ini bertujuan untuk mengetahui bagaimana strategi industri kreatif mengkomunikasikan daya tarik tempat di mana mereka berada sehingga menjadi daya tarik minat calon konsumen. Penelitian ini menggunakan teori komunikasi pemasaran dan media baru. Dan dalam menganalisis data yang diperoleh peneliti menggunakan analisis SOSTAC. Selain melakukan observasi dan studi pustaka, peneliti juga melakukan wawancara dengan pihak industri dari dua kota yang identik dengan industri kreatif yakni Bandung dan Yogyakarta yang sudah mendapat reputasi di pasar mancanegara. Dari penelitian ini ditemukan bahwa pelaku industri kreatif memiliki potensi untuk menarik minat wisatawan terutama dari luar negeri.
\end{abstract}

Kata Kunci: industri kreatif, komunikasi pemasaran, media baru

\section{Pendahuluan}

Industri kreatif di Indonesia telah menjadi bagian penting dalam pertumbuhan ekonominya. Industri kreatif telah menjadi satu pilar dalam membangun ekonomi nasional, karena mampu menciptakan sumber daya manusia 
yang berdaya saing di era globalisasi, sekaligus menyejahterakan masyarakat, yang membuatnya dipandang sangat strategis. Pesatnya pertumbuhan industri kreatif di Indonesia ini tidak lepas perkembangan media baru termasuk di dalamnya adalah media sosial. Saat ini media baru, khususnya media sosial telah menjadi sarana promosi dan komunikasi bagi industri kreatif tidak hanya kepada pasar domestik tapi luar negeri.

Seperti pada industri kreatif di sejumlah daerah di Indonesia yang telah dikenal luas di negara-negara maju. Bandung, Jawa Barat yang dikenal sebagai kota kreatif, telah melahirkan industri kreatif yang dikenal di mancanegara. Fourspeed Metalwerks, adalah industri penghasil aksesoris bagi musisi rock luar negeri. Bahkan band-band terkenal seperti Metallica dan Sepultura telah menggunakan aksesoris perusahaan Bandung ini bahkan melakukan kerja sama resmi. (finance.detik.com, 8 Januari 2014)

Sementara itu di Yogyakarta, yang juga dikenal sebagai kota industri kreatif, banyak permintaan datang dari luar negeri langsung pada kalangan industri kreatif di kota ini. Sejumlah ilustrator yang tinggal di kota Yogyakarta saat ini seperti Danang Pambayun, Anung Srihadi dan beberapa nama lain saat ini mendapat permintaan desain ilustrasi untuk produk dari luar negeri sepatu Puma, cover majalah internasional, cover musik dunia seperti Maroon5 dan Billy Joel. Bahkan nama-nama merek ternama internasional sudah menjadi klien mereka seperti Adobe, Carlsberg, Honda dan beberapa nama lainnya. (www.evergrunge.com)

Dalam bauran pemasaran (marketing mix), tempat (place) adalah salah satu yang bisa mempengaruhi pelanggan dalam mengambil keputusan (Kotler, 2002). Apa yang dimiliki dari kota, tidak hanya reputasi tapi juga daya tarik pariwisata yang ada, dapat di komunikasikan oleh penjual untuk memengaruhi pelanggan. Komunikasi itu saat ini dilakukan melalui media baru yang menjadi fokus dari penelitian ini.

Dari uraian latar belakang dapat ditemukan beberapa masalah, yakni: (1) Media baru menjadi sarana komunikasi antara industri kreatif dan pelanggan (2) Kota tempat industri kreatif memberi pengaruh pada calon konsumen (3) Kota tempat industri kreatif bisa menjadi daya tarik bagi konsumen (4) Pihak industri kreatif bisa mengkomunikasikan kepada calon konsumen tentang kota tempat mereka berada (5) Kota tempat industri kreatif memiliki potensi pariwisata. Dari uraian identifikasi masalah tadi dapat dirumuskan bahwa masalah dari penelitian adalah bagaimana industri kreatif di Bandung dan Yogyakarta dalam mengkomunikasikan kota di mana mereka berada untuk menjadi daya tarik calon konsumen dari mancanegara?

Menurut Rencana Pengembangan Ekonomi Kreatif 2025 (Departemen Perdagangan, 2008) bahwa ekonomi kreatif adalah industri yang berasal dari pemanfaatan kreativitas, ketrampilan serta bakat individu untuk menciptakan kesejahteraan serta lapangan pekerjaan melalui penciptaan dan pemanfaatan daya kreasi dan daya cipta individu tersebut. Dari definisi dapat ditarik kesimpulan bahwa industri kreatif merupakan industri yang memanfaatkan kreativitas dan inovasi yang bertujuan untuk menyalurkan ketrampilan dan bakat sehingga bisa tercipta lapangan pekerjaan melalui kreatifitas dan inovasi. 
Farid Rusdi, Gregorius Genep Sukendro : Analisis Industri Kreatif Dalam Memanfaatkan Identitas Kota Melalui Media Baru

Seiring perkembangan zaman yang semakin tumbuh pesat, banyak jenis media baru yang bermunculan di masyarakat yang mengubah spektrum dari berbagai kemungkinan tentang sosio teknologi yang berdampak terhadap komunikasi publik. Banyaknya media sosial yang bermunculan seperti facebook, twitter, instagram, dan lain-lain merupakan media baru yang membuat orang bisa berkomunikasi dan berbagi dengan teman bahkan dengan orang lain yang memiliki akun media sosial yang sama. Media sosial adalah media yang banyak digunakan oleh masyarakat sekarang ini untuk berkomunikasi. Media sosial memiliki fungsi untuk dapat mendukung interaksi sosial bagi para penggunanya. Media sosial dapat digunakan untuk berinteraksi dengan teman, berbagi informasi, juga bisa mendapatkan teman-teman baru yang sama-sama menggunakan akun media sosial tersebut. Mayfield mendefinisikan media sosial sebagai pemahaman terbaik dari kelompok jenis baru media online yang mencakup karakter-karakter partisipasi, keterbukaan, percakapan, komunitas, dan konektivitas (Mayfield, 2011).

Menurut Stanton yang dikutip oleh Saladin dan Oesman (2002) bahwa komunikasi pemasaran merupakan kombinasi dari penjualan tatap muka, periklanan, promosi penjualan, publisitas, dan hubungan masyarakat yang membantu pencapaian tujuan perusahaan. Dari pengertian di atas dapat disimpulkan bahwa komunikasi pemasaran adalah cara untuk mengkomunikasikan produk kepada konsumen dengan penggunaan unsur-unsur promosi untuk mencapai tujuan perusahaan. Komunikasi pemasaran disebut juga bauran promosi yang merupakan alat efektif untuk berkomunikasi dengan para pelanggan (baik konsumen atau perantara). Komunikasi pemasaran atau bauran promosi ini perlu ditangani secara cermat karena masalahnya bukan hanya menyangkut besarnya biaya yang digunakan. Dalam memasarkan produknya, perusahaan memerlukan suatu komunikasi maka konsumen dapat mengetahui produk yang ditawarkan oleh perusahaan.

Tempat atau lokasi di mana sebuah industri atau perusahaan berada menjadi daya tarik calon pembeli. Dalam teori bauran pemasaran (mix marketing) menyatakan bahwa ada empat hal yang perlu diperhatikan dalam memasarkan suatu produk yakni Price (harga), Promotion (Promosi), Product (Produk) dan Place (Tempat) (Kotler, 2002) (knowledge.ckgsb.edu.cn, October 8, 2013)

Place menjadi salah satu daya tarik bagi calon konsumen, jika lokasi itu mudah terjangkau atau dekat dengan si konsumen. Tapi di era media baru saat ini, beberapa kalangan memandang bahwa tempat atau lokasi tidak lagi menjadi masalah penting bagi calon konsumen, karena interaksi antara penjual dan pembeli sudah semakin mudah dengan internet. (Kumar, 2014)

Jadi pertimbangan tempat di sini adalah tidak lagi mejadi masalah mengenai jauh atau dekat, tapi salah satu di antaranya adalah masalah reputasi atau track record dari tempat di mana industri itu berada. Selain itu juga daya tarik pariwisata juga bisa menjadi minat konsumen terutama mereka dari mancanegara. Indonesia sudah dikenal pariwisatanya oleh mancanegara.

Untuk mengidentifikasi dan menganalisa strategi komunikasi pemasaran Fourspeed Metalwerks dan Evergrunge melalui media baru dalam menjangkau pasar, peneliti menggunakan model SOSTAC (Situation, Objective, Strategy, 
Tactic, Action, Control) yang dikembangkan oleh pakar pemasaran Paul R Smith pada tahun 1990an. Dengan menggunakan analisis SOSTAC, dapat diketahui kelebihan atau kekurangan dari strategi yang telah atau akan diterapkan. Ada banyak pendekatan dalam strategi komunikasi pemasaran. Walau tidak ada pendekatan tunggal, tetapi esensi perencanaan menurut elemen-elemen tertentu haruslah ada, salah satunya adalah analisis komunikasi pemasaran dengan menggunakan SOSTAC (Prisgunanto, 2006).

\section{Metode Penelitian}

Penelitian ini menggunakan metode kualitatif dengan sifat deskriptif, yang bermaksud untuk menggambarkan bagaimana temuan hasil penelitian dalam menjawab rumusan masalah yang telah dikemukakan pada bagian sebelumnya. Data dalam penelitian ini diperoleh melalui wawancara mendalam dengan narasumber, observasi, dan juga studi pustaka. Narasumber dalam penelitian adalah pihak Fourspeed Metalwerks dan Evergrunge, yang berada di Kota Bandung dan juga Yogyakarta yang merupakan para pelaku industri kreatif yang telah berhasil menembus pasar mancanagara.

Subjek dalam penelitian ini adalah pelaku industri kreatif di Bandung dan Yogyakarta, yaitu Fourspeed Metalwerks dan Evergrunge. Sedangkan objek penelitian adalah komunikasi pemasaran yang dilakukan pelaku industri kreatif tersebut. Data penelitian yang telah didapatkan, kemudian diolah dan dianalisis menggunakan analisis SOSTAC (Situation, Objective, Strategy, Tactic, Action, Control), dimana hasil temuan penelitian akan dijabarkan pada bagian berikutnya.

\section{Hasil Penemuan dan Diskusi}

Pada bagian ini akan dijelaskan mengenai hasil temuan penelitian yang kemudian dianalisis dengan menggunakan analisis SOSTAC (Situation, Objective, Strategy, Tactic, Action, Control). Pertama akan dijelaskan mengenai Fourspeed Metalwerks dan analisis SOSTAC (Situation, Objective, Strategy, Tactic, Action, Control). Kemudian dilanjutkan dengan pembahasan dari Evergrunge beserta analisis SOSTAC (Situation, Objective, Strategy, Tactic, Action, Control).

\section{Fourspeed Metalwerks}

Awal mulanya industri ini dikenal oleh mancanegara, pada tahun 2010 pemilik Fourspeed, Hedi Rusdian Gunawan memiliki ide mengirimkan sampel produknya kepada manajemen band hip hop House of Pain, tetapi ditolak. Dia lalu mendekati orang-orang di lingkaran pergaulan sosial para personel band tersebut. Usahanya tidak sia-sia, saat karyanya ditemukan sang vokalis, Danny Boy. Bahkan, Danny Boy sendiri yang kemudian menghubungi Hedi untuk mengajak bekerja sama (finance.detik.com, 8 Januari 2014).

Saat ini Fourspeed Metalwerks mampu mempekerjakan 40 orang di dua negara, yakni Indonesia dan Amerika Serikat. Mereka telah menandatangani naskah kerja sama pembuatan kepala ikat pinggang dan cincin dalam jumlah 
Farid Rusdi, Gregorius Genep Sukendro : Analisis Industri Kreatif Dalam Memanfaatkan Identitas Kota Melalui Media Baru

sangat terbatas. Rekan kerja samanya tersebut adalah band trash metal yang sudah mendunia, Sepultura.

Selain tampilan produk, situs Fourspeed juga pada kanal story menampilkan cerita yang disampaikan dalam bahasa Inggris. Cerita tentang kerajaan jaman dahulu, yang di dalamnya mengaitkannya dengan kerajaan yang ada di wilayah Nusantara. Cerita ini juga didukung dengan gambar peta Indonesia.

\section{Analisis SOSTAC (Fourspeed Metalwerks) Situation}

Perkembangan teknologi terutama pada media baru telah mempermudah komunikasi lintas negara. Hubungan konsumen dan produsen semakin dekat dalam perdagangan. Keadaan ini semakin memungkinkan bagi industri kecil dan menengah bersaing dan dikenal oleh pasar luar negeri. Hal ini sebagaimana dilakukan oleh Fourspeed yang memiliki pasar di mancanegara. Media baru yang dimanfaatkan oleh untuk berinteraksi dengan konsumen. Dan melalui media ini, konsumen juga bisa mengenal latar belakang tempat Fourspeed.

\section{Objective}

Pemilik Fourspeed memiliki visi untuk membuat sebuah brand yang bisa menjadi ikon untuk lelaki (indotrading.com, 14 Desember 2016). Selain itu Fourspeed juga memiliki misi meningkatkan gairah industri kreatif di Indonesia. Dengan menggunakan 'amunisi' lokal untuk tema-tema produk yang dihasilkan sehingga industri kreatif lokal bisa dikenal oleh konsumen mancanegara.

\section{Strategy}

Melalui situsnya di internet, Fourspeed memperkenalkan Indonesia dengan menampilkan peta Indonesia yang mewarnai tema "Return of The King". Selain itu beberapa produknya seperti cincin menggunakan penamaan "Patih Gajah Mada".

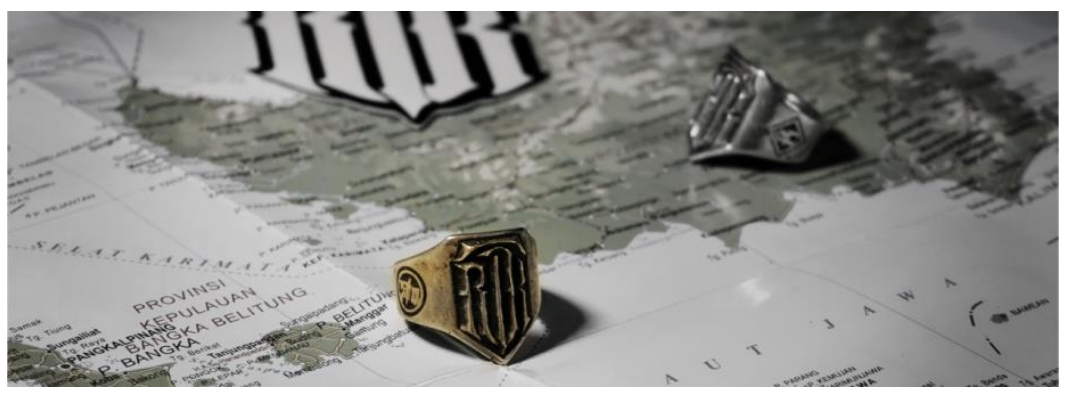

Gambar 1: Tampilan situs Fourspeed

\section{Tactics}

Fourspeed menyajikan potensi lokal dengan menggunakan tema "Return of The King". Tema ini juga terkait dengan produk-produk yang mereka hasilkan. Action

Penyajian tema tersebut menggunakan peta Indonesia dan produk-produk Fourspeeed seperti cincin dan kepala ikat pinggang. 


\section{Control}

Tema yang disajikan Fourspeed melalui situsnya di internet dievaluasi untuk menyiapkan tema-tema yang bisa menarik pelanggan dengan memperkenalkan potensi lokal yang ada.

\section{Evergrunge}

Evergrunge adalah situs internet dari illustrator Dhanank Pambayun yang berdomisili di Yogyakarta. Ilustrator digital lulusan AKSERI Yogyakarta ini mendirikan Evergrunge Inc.yang menjadi ruang pamer resmi untuk pekerjaan profesionalnya, dan Project Alkafiksi.ruang untuk menerbitkan buku cerita bergambar versi online.

Ia telah membuat ilustrasi untuk beberapa band komersial, editorial serta terlibat dalam pameran seni offline dan online, seperti The Outstanding Rock Short Film and Video Festival di Ohio (2004); Digital Spirit Republicart Project di Yogyakarta (2006); UK Digital Art Show, Annually Digital Art Exhibition di Inggris (2006); Massive Offline International Digital Art Exhibition di Jakarta (2006); Selvolution Jogjaforce di Yogyakarta (2008); ArtCafe Exhibition di Moskow (2010); dan NINH, Fashion and Art Exhibition di New York (2010).

Ia pernah diminta oleh ARDT Singapore sebagai ilustrator $t$-shirt untuk proyek Holy Suicide (2009) dan memberikan desain ilustrasinya, Cosmos in Lap, untuk buku Backstage Designers Book yang diterbitkan oleh Uberbook (2010). Karya vektornya pernah digunakan sebagai materi promosi produk Puma dalam Puma Football Series yang diminta oleh Robert/Boisen \& Like Minded, DK (2008); dan motor Honda, New CBR 600 RR yang diminta oleh Dailey Adv. \& Association, Amerika Serikat (2007).

Selain melalui Evergrunge, Dhanank Pambayun juga memamerkan portofolionya melalui https://www.behance.net/evergrunge. Dengan tetap mengedepankan nama Evergrunge, dalam laman situs ini ia menyebutkan bahwa illustrator Evergrunge berdomisili di Yogyakarta, Indonesia.

\section{Analisis SOSTAC (Evergrunge) Situation}

Evergrunge memamerkan karya yang menjadi porto polio selama ini di situs Evergrunge.com dan behance.net/evergrunge di internet.

\section{Objective}

Melalui laman situs Evergrunge, calon klien terutama dari luar negeri bisa mengenal tidak hanya karya Dhanank Pambayun, tapi juga potensi industri kreatif Yogyakarta.

\section{Strategy}

Dengan menunjukkan identitas domisili dari ilustrator yang menetap di Yogyakarta, bisa memberi kesadaran kognitif bagi klien-klien terutama dari luar negeri tentang kota Yogyakarta. 


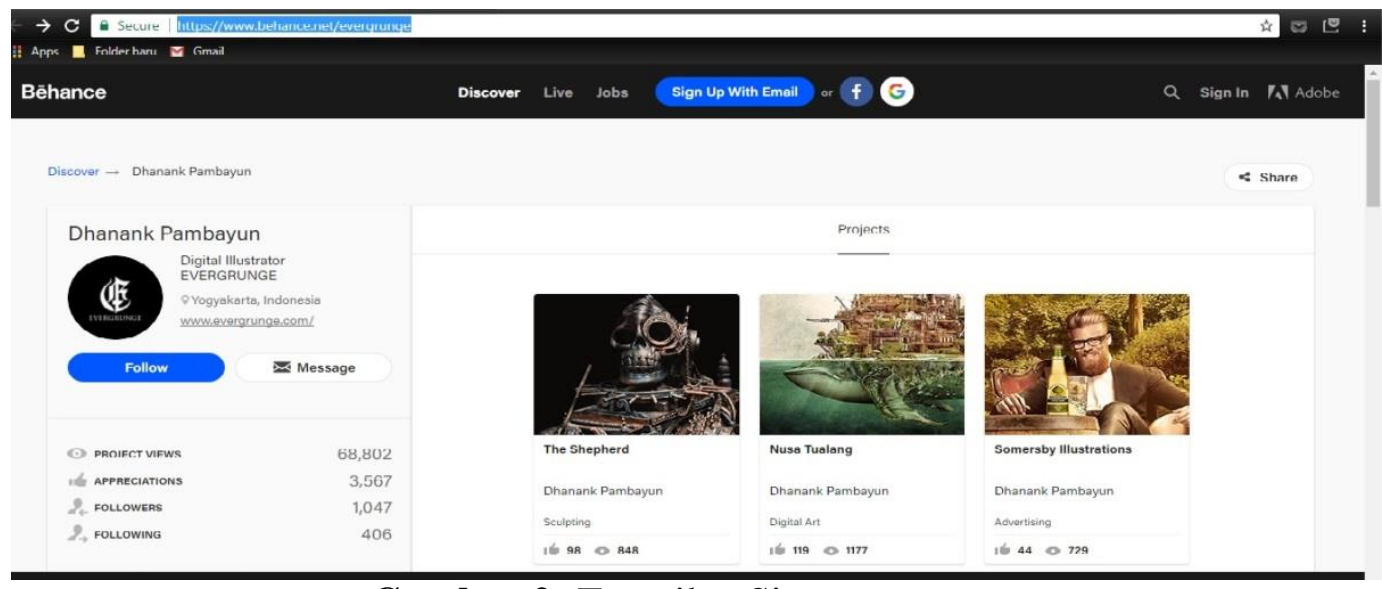

Gambar 2: Tampilan Situs evergrunge

\section{Tactic}

Belum ada kegiatan pada tahapan ini yang secara detil bisa menarik minat klien-klien dari luar negeri untuk berkunjung ke Yogyakarta.

\section{Action}

Dhanank Pambayun menjelaskan saat ini ada beberapa kliennya yang datang ke Yogyakarta dan mengujungi tempat wisata. Ia mengakui keingintahuan dari beberapa kliennya saat berkunjung ke Yogyakarta, dan selama ini untuk menjawab keingintahuan itu dilakukan dengan komunikasi langsung.

\section{Control}

Melihat proses yang telah dilakukan selama ini, maka perlu adanya evaluasi dengan memperbaiki proses yang sudah ada.

\section{Simpulan}

Kesimpulan dari penelitian yang dilakukan adalah bahwa Fourspeed Metalwerks telah berupaya melalui situs internetnya untuk memperkenalkan identitas lokal kepada calon konsumennya dari mancanegara. Meski upaya itu masih belum dengan jelas mengedepankan identitas kota Bandung tempat Fourspeed berada, tapi kemungkinan hal itu bisa dilakukan dengan pengembangan konten-konten yang ada pada situs.

Sementara dari Yogyakarta, Evergrunge yang dimiliki oleh illustrator digital Dhanank Pambayun, secara tidak langsung telah memperkenalkan Yogyakarta kepada para kliennya yang ada di luar negeri. Dengan menunjukkan identitas domisili tempat ia menetap yakni Yogyakarta, klien menjadi mengenal dan tertarik untuk datang. Beberapa klien dari Evergrunge ada yang sudah berkunjung ke Yogyakarta untuk berwisata.

Sebagai masukan atas dasar dari hasil penelitian ini adalah dibutuhkan campur tangan dari pemerintah untuk membantu para pelaku industri kreatif untuk memperkenalkan tentang identitas kota. Hal yang serupa juga disebutkan dalam hasil penelitian Arina (2014) mengenai branding Kota Cimahi sebagai kota kreatif. Diperlukan peran aktif pemerintah untuk menjadi perantara komunikasi yang dilakukan industri kreatif. 


\section{Ucapan Terima Kasih}

Penulis mengucapkan terima kasih kepada seluruh narasumber, yaitu Fourspeed Metalwerks yang berdomisili di Bandung dan Evergrunge yang berdomosili di Yogayakarta, yang telah bersedia bekerja sama dan memberikan waktu dalam proses pengumpulan data penelitian ini. kemudian ucapan terima kasih juga diberikan kepada Kemenristekdikti sebagai pemberi dana hibah penelitian. Terakhir kepada seluruh rekan-rekan diskusi di Fakultas Ilmu Komunikasi Universitas Tarumanagara.

\section{Daftar Pustaka}

Arina, Nada. (2014). Transformasi Branding Kota Cimahi Sebagai Kota Kreatif. Jurnal Komunikasi, vol 6, no.2, 34-41. Terarsip di : https://journal.untar.ac.id/index.php/komunikasi/article/view/31

Departemen Perdagangan. (2008). Rencana Pengembangan Ekonomi Kreatif 2025.

Evergrunge.

(n.d.). Evergrunge.

(http://evergrunge.com/versi13/?page_id=2)

Finance.detik.com. (2014, Januari 8). Pengusaha Muda Ini Paling Dicari Personel Band Metal di Dunia. Terarsip di: http://finance.detik.com/read/2014/01/08/174720/2462008/480/pengusahamuda-ini-paling-dicari-personel-band-metal-di-dunia

Indotrading.com. (2016, Desember 14). Fourspeed Metalwerks Bisnis Aksesoris Beromzet Ratusan Juta yang Laris di Eropa Hingga Amerika. Terarsip di: https://news.indotrading.com/fourspeed-metalwerks-bisnis-aksesorisberomzet-ratusan-juta-yang-laris-di-eropa-hingga-amerika

Kotler, Phillip. (2002). Manajemen Pemasaran. Jakarta: PT Prenhallindo.

Knowledge.cksb.edu.cn. (8 October 2013). The Thinker Interview with Philip Kotlerr, the Father of Marketing. Terarsip di: http://knowledge.ckgsb.edu.cn/2013/10/08/marketing/philip-kotler-fourps-model-marketing-still-king/

Kumar, Sunil. (2014). Marketing Management: Marketing Mix-An Introduction. Internasional Journal of Engineering Research and Management Technology, Volume-1, Issue-1. Terarsip di: http://citeseerx.ist.psu.edu/viewdoc/download;jsessionid=A04E06157A46 6C0FD43197348A5A1012?doi=10.1.1.673.1062\&rep=rep1\&type=pdf

Mayfield, Anthony. (2011). What Is Social Media. iCrossing. (http://www.icrossing.co.uk/fileadmin/uploads/eBooks/What_is_Social_M edia_iCrossing_ebook.pdf)

Prisgunanto, Ilham. (2006). Komunikasi Pemasaran: Strategik dan Taktik. Bogor: Penerbit Ghalia Indonesia.

Saladin, Djaslim., \& Yavis, Marty Oesman. (2002). Intisari Pemasaran dan Unsurunsur Pemasaran. Bandung: PT. Linda Karya. 